\title{
Increased glucocorticoid sensitivity in islet beta-cells: effects on glucose 6-phosphatase, glucose cycling and insulin release
}

\author{
Z-C.Ling ${ }^{1}$, A. Khan ${ }^{1}$, F. Delauny ${ }^{2}$, B. Davani ${ }^{2}$, C-G.Östenson ${ }^{1}$, J-Å. Gustafsson ${ }^{2}$, S. Okret ${ }^{2}$, BR. Landau ${ }^{3}$, S. Efendic ${ }^{1}$ \\ ${ }^{1}$ Department of Molecular Medicine, Endocrine and Diabetes Unit, Karolinska Hospital, Stockholm, Sweden \\ ${ }^{2}$ Department of Medical Nutrition, Karolinska Institute, Huddinge University Hospital, Huddinge, Sweden \\ ${ }^{3}$ Departments of Medicine and Biochemistry, Case Western Reserve University, Cleveland, Ohio, USA
}

\begin{abstract}
Summary Glucose-6-phosphatase (G6Pase) activity and the rate of glucose cycling are increased in islets from animal models of Type II (non-insulin-dependent) diabetes mellitus. Glucocorticoid treatment further stimulates these processes and inhibits glucose-induced insulin release. To determine whether these effects result from a direct action of glucocorticoids on the beta-cells, we used isolated islets. The islets were from transgenic mice overexpressing the glucocorticoid receptor in their beta-cells to increase the cells' sensitivity to glucocorticoid. Islets from transgenic and non-transgenic control mice utilized and oxidized the same amount of glucose. In contrast, islet G6Pase activity was $70 \%$ higher, glucose cycling
\end{abstract}

was increased threefold and insulin release was $30 \%$ lower in islets from transgenic mice. Hepatic G6Pase activity was the same in transgenic and control mice. Dexamethasone administration increased G6Pase activity and glucose cycling and decreased insulin release in both transgenic and control mouse islets. We conclude that glucocorticoids stimulate islet G6Pase activity and glucose cycling by acting directly on the beta-cell. That activity may be linked to the inhibition of insulin release. [Diabetologia (1998) 41: 634-639]

Keywords Glucose-6-phosphatase, insulin release, glucose metabolism, glucocorticoid sensitivity, transgenic mice.
Glucose-6-phosphatase (G6Pase) and glucokinase activities can be demonstrated in pancreatic islets from mammalian species [1-4]. Glucokinase appears to be the rate limiting enzyme of glycolysis in the beta-cell, regulating the dose-response relationship between glucose utilization and insulin release [4]. Since G6Pase opposes the action of glucokinase, a possible role for G6Pase in the metabolic regulation of insulin release was postulated [2,3]. There are several reports of relatively low G6Pase activity in homogenates of normal mammalian islets [1-4], one

Received: 14 November 1997 and in revised form: 23 January 1998

Corresponding author: Dr. S. Efendic, Department of Molecular Medicine, Endocrine and Diabetic Unit, Karolinska Hospital, S-17676 Stockholm, Sweden

Abbreviations: G6Pase, Glucose-6-phosphatase; GR, glucocorticoid receptor; HEPES, N-[2-hydroxyethyl] piperazine-2ethane sulphonic acid. of activity exceeding that in liver [5] and one of no activity [6]. We found low activity in permeabilized and sonicated islets from normal rats and mice [7]. Sweet et al. [8] also found low G6Pase activity in intact islets from normal rats.

Glucose cycling is the simultaneous phosphorylation of glucose to glucose-6-P and dephosphorylation of glucose-6-P to glucose with the resulting consumption of ATP [9]. In accordance with reports of low G6Pase activity, we demonstrated a low rate of glucose cycling in intact islets from normal mice, dephosphorylation occurring at only $3 \%$ of the rate of phosphorylation [10]. However, in islets from ob/ob mice, $30-40 \%$ of phosphorylated glucose was dephosphorylated [10]. Glucose cycling was also increased in islets from other animal models of Type II diabetes $[11,12]$. In accordance with these results, G6Pase activity was several fold higher in islets from diabetic than normal animals $[7,13]$ and islet G6Pase gene expression was increased during the development of diabetes in Zucker rats [14]. 
Glucocorticoids increase hepatic glucose production and decrease glucose uptake in man [15]. Increased glucose production is accompanied by increased gluconeogenesis and associated with enhanced G6Pase gene expression and enzyme activity $[16,17]$. Recently, a glucocorticoid response element was identified in the human G6Pase gene promoter, suggesting that the effects of glucocorticoids on G6Pase are directly mediated by the glucocorticoid receptor (GR) [18]. We previously reported an increase of G6Pase activity in islets from ob/ob mice treated with dexamethasone [7], indicating the enzyme's activity is also regulated in islets by glucocorticoids. This effect was associated with increased glucose cycling and decreased insulin release suggesting a role for G6Pase in insulin release. However, those findings could not be ascribed to a direct action of glucocorticoids on the beta-cell, since glucocorticoids have multiple effects on whole body glucose homeostasis as well as on non beta-cells, including glucagonproducing cells $[15,19]$.

Recently, Trinh et al. overexpressed the hydrolase catalytic subunit of the hepatic G6Pase complex in an insulinoma cell line [20]. They observed increased glucose cycling and decreased insulin secretion, but not the marked alteration in beta-cell metabolism found in the rodent models of obesity and Type II diabetes. Therefore, they postulated the possible involvement of genes, in addition to the hydrolase, in the etiology of beta-cell dysfunction in these models.

By overexpressing GR in the beta-cell, we recently generated transgenic mice with increased beta-cell glucocorticoid sensitivity [21]. The mice exhibited mild glucose intolerance and a dramatic decrease in acute insulin response. In the present study, we used isolated islets from the mice to examine the consequence of an increased beta-cell glucocorticoid sensitivity on G6Pase activity, glucose cycling and insulin release.

\section{Materials and methods}

Materials. $\left[1-{ }^{14} \mathrm{C}\right]$ Glucose-6-P (specific activity $60 \mathrm{mCi} / \mathrm{mmol}$ ), $\left[5-{ }^{3} \mathrm{H}\right]$ glucose $(15.7 \mathrm{Ci} / \mathrm{mmol})$ and tritiated water $(100 \mathrm{mCi} /$ ml) were purchased from DuPont NEN (Boston, Mass. USA). Glucose-6-P, $\beta$-glycerol-P, (N-[2-hydroxyethyl]piperazine-N'-2-ethane sulphonic acid) (HEPES) and bovine serum albumin (fraction V) were purchased from Sigma Chemical Co. (St. Louis, Mo., USA). Amberlite MB-3 monobed resin was purchased from BDH Ltd. (Poole, UK). Collagenase was purchased from Boehringer Mannheim GmbH (Mannheim, Germany).

Animals. Control and transgenic mice, 3-4 months old, weighing 20-29 g, were used. Increased beta-cell sensitivity to glucocorticoids in the transgenic mice was achieved by overexpressing the GR under the control of the insulin promoter [22]. The characteristics of these animals have been described previously [21].
Isolation of islets. One group of control and transgenic mice was killed to isolate pancreas and liver. A second group was injected i.p. with dexamethasone, $25 \mu \mathrm{g}$ in $0.25 \mathrm{ml}$ saline or saline only, at 0900 hours on the first day of the study and again at 0900 hours on the second and third days. The mice were killed by decapitation $2 \mathrm{~h}$ after injection on the third day. Blood was collected for determination of plasma glucose concentration. Pancreata were digested for 10-12 min under continuous shaking ( 150 strokes $/ \mathrm{min})$ at $37^{\circ} \mathrm{C}$ in $2.5-3.0 \mathrm{ml}$ of Hank's balanced salt solution containing $6-8 \mathrm{mg}$ collagenase. An additional $15-20 \mathrm{ml}$ of the cold balanced salt solution was added and the suspension was allowed to settle. The sediment was washed several times with the cold solution and the islets from the sediment were collected using a glass pipette under stereomicroscopy.

Preparation of hepatic microsomes. All procedures were performed at $0-4{ }^{\circ} \mathrm{C}$. Livers from control and TG mice were homogenized in $250 \mathrm{mmol} / \mathrm{l}$ sucrose, $10 \mathrm{mmol} / 1$ HEPES buffer $(\mathrm{pH} 7.5)$ and the microsomes were collected by differential centrifugation. They were re-suspended in the sucroseHEPES buffer at a final concentration of 3-5 $\mu \mathrm{g}$ protein/ $10 \mu \mathrm{l}$. Disrupted microsomes were prepared by preincubating the microsomes with $0.1 \%$ Triton for $20 \mathrm{~min}$ in ice-water and then diluting with sucrose-HEPES to the same protein concentration as for the intact microsomes. Microsomes were regarded as "intact" if the latency of mannose-6-phosphohydrolase activity was more than $90 \%$, i.e less than $10 \%$ of the activity exhibited in the absence of Triton was observed in its presence [23].

Glucose cycling, glucose utilization and oxidation. Glucose cycling was determined from the incorporation of ${ }^{3} \mathrm{H}$ at position 2 of glucose after incubation of islets with ${ }^{3} \mathrm{H}_{2} \mathrm{O}$ and unlabelled glucose. Estimates depend on the assumption that before each molecule of glucose 6-P is hydrolysed to glucose, because of rapid equilibration between glucose 6-P and fructose 6-P, a hydrogen from the medium is bound to carbon 2 of the glucose 6-P. Rapid equilibration of glucose 6-P with fructose 6-P is expected because of a relatively high activity of phosphohexose isomerase in islets [24]. Isotopic equilibration in human liver was estimated to reach $80-92 \%$ [25]. To the extent isotopic equilibration is incomplete, cycling is underestimated.

For the determination of glucose cycling, 25 islets were placed in an incubation vial with $16.7 \mathrm{mmol} / \mathrm{l}$ glucose, $0.5 \%$ bovine albumin and $2.5 \mathrm{mCi}$ of ${ }^{3} \mathrm{H}_{2} \mathrm{O}$ in $50 \mu \mathrm{l}$ of Krebs-bicarbonate buffer ( $\mathrm{pH} 7.4)$. Each vial with its content was placed in a scintillation bottle, sealed and gassed with $\mathrm{O}_{2} / \mathrm{CO}_{2}$ (19:1 by volume) for $3 \mathrm{~min}$. After $2 \mathrm{~h}$ incubation at $37^{\circ} \mathrm{C}, 100 \mu \mathrm{l}$ of perchloric acid was injected into the vial. The vial was removed from the scintillation bottle and $2 \mathrm{mg}$ of glucose was added. The contents were centrifuged for $2 \mathrm{~min}$ (10000 g), the supernatant neutralized with $\mathrm{KOH}$ and the precipitated potassium perchlorate removed by centrifugation. The resulting supernatant was passed through the MB-3 resin. The effluent was freeze dried several times and the residue dissolved in water and subjected to HPLC (HPX-87P system, Bio-Rad, Hercules, Calif. USA) to purify the glucose. A portion of the purified glucose was assayed for radioactivity and glucose concentration determined using a glucose oxidase method (Glucose Analyser, Model 23A, Yellow Springs Co., Yellow Springs, Ohio, USA). Another portion of the purified glucose was incubated with glucose oxidase and the resulting reaction mixture was deionized, concentrated and the concentrate chromatographed. No radioactivity was found with the mobility of glucose after incubation with glucose oxidase. 
For the measurements of glucose oxidation and utilization, 25 islets were incubated in an identical manner to that with ${ }^{3} \mathrm{H}_{2} \mathrm{O}$, except that instead the islets were incubated with [U$\left.{ }^{14} \mathrm{C}\right]$ glucose and $\left[5-{ }^{3} \mathrm{H}\right]$ glucose. The incubation time was $1.5 \mathrm{~h}$. After incubation, $100 \mu \mathrm{l}$ of $10 \%$ perchloric acid was injected into the vial and $250 \mu \mathrm{l}$ of Hyamine (Packard Instrument Co., Meriden, Conn., USA) and $250 \mu$ of water were injected into the bottle to absorb ${ }^{14} \mathrm{CO}_{2}$ and ${ }^{3} \mathrm{H}_{2} \mathrm{O}$. Parallel incubation was performed, but without islets.

${ }^{14} \mathrm{CO}_{2}$ and ${ }^{3} \mathrm{H}_{2} \mathrm{O}$ were collected overnight. The vial with its acidified contents was removed and scintillation fluid (Ultima Gold, Packard Instrument Co.) added to the bottle, which was then assayed for ${ }^{14} \mathrm{C}$ and ${ }^{3} \mathrm{H}$ in dual channels using a liquid scintillation spectrophotometer (Packard Instrument Co., TriCarb 1900 TR Liquid Scintillation Analyser). The recovery of ${ }^{14} \mathrm{CO}_{2}$ and ${ }^{3} \mathrm{H}_{2} \mathrm{O}$ was assayed by incubating medium containing sodium ${ }^{14} \mathrm{C}$ bicarbonate and ${ }^{3} \mathrm{H}_{2} \mathrm{O}$ without islets and collecting ${ }^{14} \mathrm{CO}_{2}$ and ${ }^{3} \mathrm{H}_{2} \mathrm{O}$ in an identical manner.

Islet G6Pase activity. Batches of 25 islets were placed in tubes containing $50 \mathrm{mmol} / \mathrm{l}$ HEPES (pH 7.4) with $20 \mathrm{mmol} / \mathrm{l} \beta$-glycerol-P and sonicated $10 \mathrm{~s}$ to disrupt the islets [7]. $\beta$-glycerol$\mathrm{P}$ was added to the incubation medium to inhibit non-specific phosphatase activity. $0.5 \mu \mathrm{Ci}\left[1-{ }^{14} \mathrm{C}\right]$ glucose-6-P $(4 \mathrm{mmol} / \mathrm{l})$ was added to each tube, mixed and incubated for $20 \mathrm{~min}$ at $37^{\circ} \mathrm{C}$. The volume of incubation medium was $200 \mu$ l. Parallel incubations were performed without islets. Incubation was stopped by placing the incubate in ice-water and adding $200 \mu \mathrm{l}$ of $0.3 \mathrm{~mol} / 1 \mathrm{ZnSO}_{4}$, and after mixing, $200 \mu \mathrm{l}$ of a saturated solution of $\mathrm{Ba}(\mathrm{OH})_{2}$. Then, $2 \mathrm{mg}$ of carrier glucose was added to each incubation vial and glucose isolated from the reaction mixture as described above.

Hepatic G6Pase activity. Hepatic microsomes were incubated for $10 \mathrm{~min}$ at $37^{\circ} \mathrm{C}$ in a medium containing $4 \mathrm{mmol} / 1$ glucose 6-P, $0.1 \mu \mathrm{Ci}\left[1-{ }^{14} \mathrm{C}\right]$ glucose $6-\mathrm{P}, 2-5 \mu \mathrm{g}$ of microsomal protein, $50 \mathrm{mmol} / \mathrm{l}$ sodium acetate in a total volume of $50 \mu \mathrm{l}$. Incubation was stopped by placing the tubes in ice-water and adding $50 \mu \mathrm{l}$ $0.3 \mathrm{~mol} \mathrm{ZnSO}_{4}$ and after mixing $50 \mu \mathrm{l}$ of a saturated solution of $\mathrm{Ba}(\mathrm{OH})_{2}$. Then again $2 \mathrm{mg}$ of carrier glucose was added to each incubation vial and glucose isolated as described above. The activity of G6Pase in intact endoplasmic reticulum membrane estimates the translocase function, whereas disruption of the membrane by Triton provides a measure of the hydrolase component [23].

Insulin release. Batches of three islets were incubated in triplicate for $1 \mathrm{~h}$ at $37^{\circ} \mathrm{C}$ in $300 \mu \mathrm{l}$ Krebs bicarbonate buffer (pH 7.4), containing $2 \mathrm{mg} / \mathrm{ml}$ bovine albumin and 5.5 or $16.7 \mathrm{mmol} / \mathrm{l}$ glucose. After incubation, an aliquot of the medium was stored at $-70^{\circ}$ for insulin assay. Insulin was measured by radioimmunoassay with the addition of charcoal to separate free and bound antibody [26]. The sensitivity of the assay was $6 \mu \mathrm{U} / \mathrm{ml}$, and the inter- and intra-assay coefficients of variation were $10 \%$. The islets from the incubation medium were washed with Krebs bicarbonate buffer and insulin was extracted with acid-ethanol. Islet DNA content was assayed in batches of 25 islets using a fluorometric method modified by Hinegardner [27].

Calculations. Glucose cycling was calculated from the dpm per min from ${ }^{3} \mathrm{H}_{2} \mathrm{O}$ in the glucose and the amount of $\left[5-{ }^{3} \mathrm{H}\right]$ glucose (pmol) utilized by the islets. The dpm in the HPLC glucose peak multiplied by 2.15 , i.e. $2.0 \mathrm{mg}$ of glucose added at the end of the incubation plus $0.15 \mathrm{mg}$ of glucose in the medium at the beginning of incubation, and divided by the milligrams of glucose in the peak fraction gave the dpm of ${ }^{3} \mathrm{H}$ from the
Table 1. Characteristics of control and transgenic mice

\begin{tabular}{lcc}
\hline & Control $(n=17)$ & Transgenic $(n=17)$ \\
\hline Weight $(\mathrm{g})$ & $29.6 \pm 1.1$ & $28.1 \pm 1.9$ \\
Plasma glucose (mmol/l) & $4.9 \pm 0.3$ & $5.6 \pm 0.4$ \\
Islet DNA (ng/islet) & $29.3 \pm 5.8$ & $26.8 \pm 1.6$ \\
Insulin content ( $\mu \mathrm{U} /$ islet $)$ & $214.8 \pm 19.7$ & $226.7 \pm 26.6$ \\
\hline
\end{tabular}

Results are expressed as means \pm SEM

Table 2. Glucose utilization, oxidation and cycling in control and transgenic mice islets incubated at glucose concentrations of 5.5 and $16.7 \mathrm{mmol} / \mathrm{l}$

\begin{tabular}{|c|c|c|c|c|}
\hline Parameters & $n$ & Control & Transgenic & $\begin{array}{l}\text { Glucose } \\
(\mathrm{mmol} / \mathrm{l})\end{array}$ \\
\hline $\begin{array}{l}\text { Glucose utilization } \\
\left(\mathrm{pmol} \times \text { islet }^{-1} \times \mathrm{h}^{-1}\right)\end{array}$ & 6 & $\begin{array}{l}24.8 \pm 1.9^{\mathrm{a}} \\
54.4 \pm 3.3\end{array}$ & $\begin{array}{l}30.7 \pm 2.9^{\mathrm{a}} \\
61.4 \pm 6.1\end{array}$ & $\begin{array}{r}5.5 \\
16.7\end{array}$ \\
\hline $\begin{array}{l}\text { Glucose oxidation } \\
\left(\mathrm{pmol} \times \text { islet }^{-1} \times \mathrm{h}^{-1}\right)\end{array}$ & 6 & $\begin{array}{l}10.8 \pm 0.7^{\mathrm{b}} \\
29.5 \pm 2.1\end{array}$ & $\begin{array}{l}11.9 \pm 1.2^{\mathrm{b}} \\
28.5 \pm 2.5\end{array}$ & $\begin{array}{r}5.5 \\
16.7\end{array}$ \\
\hline Glucose cycling (\%) & 5 & $5.9 \pm 1.0$ & $16.5 \pm 2.9^{c}$ & 16.7 \\
\hline
\end{tabular}

Results are expressed as \pm SEM. ${ }^{\mathrm{a}} p<0.001 \mathrm{vs} 16.7 \mathrm{mmol} / \mathrm{l}$, glucose utilization; ${ }^{\mathrm{b}} p<0.001$ vs $16.7 \mathrm{mmol} / \mathrm{l}$, glucose oxidation; ${ }^{\mathrm{c}} p<0.05$ vs control, glucose cycling

${ }^{3} \mathrm{H}_{2} \mathrm{O}$ incorporated into glucose. Because there are $0.55 \times 10^{10}$ $\mathrm{dpm}$ in $2.5 \mathrm{mCi}$ of ${ }^{3} \mathrm{H}$ and $0.55 \times 10^{10}$ picoatoms of hydrogen in $50 \mu \mathrm{l}$ of water, the dpm in glucose equals the picoatoms of ${ }^{3} \mathrm{H}$ incorporated into glucose. Fraction of ${ }^{3} \mathrm{H}$ incorporated to carbon 2 of glucose was taken as 0.45 for both control and TG mice. Glucose cycling in percent was then $100\left({ }^{3} \mathrm{H}\right.$ bound to carbon 2 of glucose)/(glucose utilization $+{ }^{3} \mathrm{H}$ bound to carbon 2 of glucose).

G6Pase activity in the incubations with islets and microsomes was taken as the amount of glucose 6-P hydrolysed to glucose, traced with ${ }^{14} \mathrm{C}$. The specific activity of $\left[1-{ }^{14} \mathrm{C}\right]$ glucose $6-\mathrm{P}$ in the incubate was calculated from the quantity of glucose 6-P in the incubate (pmoles) and the amount of ${ }^{14} \mathrm{C}$ in that glucose 6-P. The dpm in the $2 \mathrm{mg}$ glucose in the incubation medium after stopping the incubation and adding the $2 \mathrm{mg}$ of carrier glucose was calculated from the ${ }^{14} \mathrm{C}$ activity $(\mathrm{dpm})$ in the effluent from the HPLC column and the amount of glucose in the effluent. The pmoles of glucose 6-P hydrolysed to glucose were then calculated by dividing the dpm in $2 \mathrm{mg}$ of glucose by the specific activity of $\left[1-{ }^{14} \mathrm{C}\right]$ glucose $6-\mathrm{P}$ in $\mathrm{dpm} / \mathrm{pmol}$ after subtracting the dpm in $2 \mathrm{mg}$ of glucose when the identical incubation was done, except in the absence of islets. Activities of hepatic G6Pase are expressed per mg of microsomal protein. Protein concentration in microsomes was determined using a Bio-Rad method [28]. Results are expressed as means \pm SEM. Differences between groups were tested for significance using Student's $t$ test for unpaired data. cant.

A p value less than 0.05 was considered statistically signifi-

\section{Results}

The transgenic mice overexpressing the glucocorticoid receptor in their beta-cells and non-transgenic control mice had similar body weights and plasma glucose concentrations (Table 1). Content of DNA and insulin in isolated islets did not differ between 
Table 3. Glucose-6-phosphatase activity in islets from control and transgenic mice treated with saline or dexamethasone (Dex).

\begin{tabular}{llll}
\hline Treatment & $n$ & \multicolumn{2}{l}{$\begin{array}{l}\text { Glucose-6-phosphatase activity } \\
\left(\mathrm{pmol} \times \text { islet }^{-1} \times \mathrm{min}^{-1}\right)\end{array}$} \\
\cline { 3 - 4 } & & Control & Transgenic \\
\hline Saline & 8 & $2.3 \pm 0.4$ & $3.6 \pm 0.4^{\mathrm{a}}$ \\
Dex & 8 & $4.0 \pm 0.5$ & $6.3 \pm 0.4^{\mathrm{b}}$ \\
\hline
\end{tabular}

Results are expressed as means \pm SEM. ${ }^{a} p<0.05$ vs control, saline treated; ${ }^{b} p<0.01$ vs control, dexamethasone treated

Table 4. Hepatic glucose-6-phosphatase activity in control and transgenic mice treated with saline or dexamethasone (Dex)

\begin{tabular}{|c|c|c|c|c|c|}
\hline \multirow[t]{3}{*}{ Treatment } & \multirow[t]{3}{*}{$n$} & \multicolumn{4}{|c|}{$\begin{array}{l}\text { Glucose-6-phosphatase activity } \\
(\mathrm{nmol} \times \mathrm{mg} \text { protein } \\
\left.-1 \times \min ^{-1}\right)\end{array}$} \\
\hline & & \multicolumn{2}{|c|}{ Translocase } & \multicolumn{2}{|c|}{ Hydrolase } \\
\hline & & Control & Transgenic & Control & Transgenic \\
\hline Saline & 5 & $110 \pm 19$ & $106 \pm 15$ & $182 \pm 32$ & $182 \pm 23$ \\
\hline Dex & 5 & $150 \pm 21$ & $162 \pm 26$ & $230 \pm 49$ & $216 \pm 25$ \\
\hline
\end{tabular}

Results are expressed as mean \pm SEM

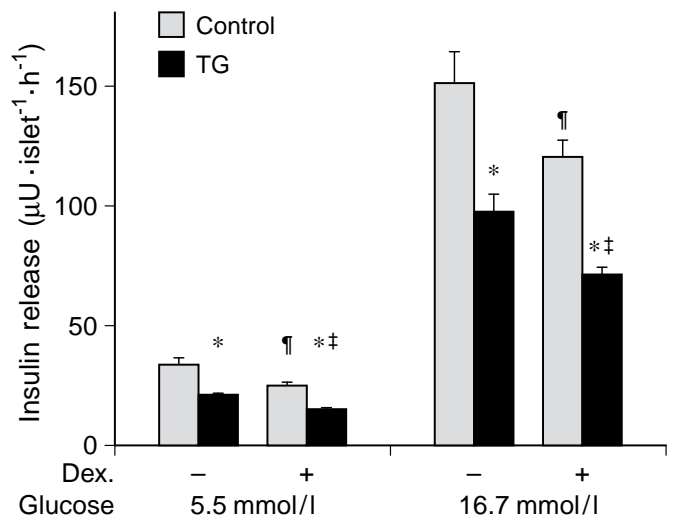

Fig. 1. Glucose induced insulin release in islets from control and TG mice treated with saline $(n=8)$ and dexamethasone (Dex;) $(n=8)$ at 5.5 and $16.7 \mathrm{mmol} / 1$ glucose. $* p<0.05$ control vs TG mice; ${ }^{\uparrow} p<0.05$ saline vs dexamethasone treatment of control mice, ${ }^{t} p<0.05$ saline vs dexamethasone treatment of TG mice

the transgenic and control group (Table 1). Islets from transgenic mice utilized and oxidized as much glucose as islets from control mice, utilizing and oxidizing 2-3 times as much at 16.7 as at $5.5 \mathrm{mmol} / \mathrm{lglu}-$ cose (Table 2). In contrast, at $16.7 \mathrm{mmol} / \mathrm{l}$ glucose, $16 \%$ of glucose phosphorylated by islets from transgenic mice was dephosphorylated, 3 times more than by control islets (Table 2). G6Pase activity in transgenic mice islets was $57 \%$ higher than in control islets (Table 3). When groups of transgenic and control mice were treated with dexamethasone for 2 days prior to isolation of islets, G6Pase activity was increased about $75 \%$ in both groups (Table 3 ). In con- trast, G6Pase activity was similar in hepatic microsomes from transgenic and control mice and dexamethasone treatment increased translocase activity about $45 \%$ and hydrolase activity about $25 \%$ (Table 4). Similar G6Pase activity in livers of transgenic and control mice and increased activity in transgenic mouse islets demonstrate that the overexpression of GR is specific to the islet beta-cell. Islets from transgenic mice incubated with 5.5 and $16.7 \mathrm{mmol} / \mathrm{l}$ glucose released $30 \%$ less insulin than islets from control mice, with 4-5 times as much insulin released at 16.7 as $5.5 \mathrm{mmol} / \mathrm{l}$ glucose (Fig. 1). Dexamethasone treatment decreased the insulin release from both groups by about $35 \%$. Thus, increased glucocorticoid sensitivity in islet beta-cells results in increased G6Pase activity and glucose cycling and decreased insulin release.

\section{Discussion}

Biological effects of glucocorticoids are mediated through the GR and the intracellular GR concentration is a major factor determining the sensitivity of target cells to the glucocorticoids [29]. Since in our transgenic mouse, the overexpression of the GR transgene is controlled through the insulin promoter, the increased effect of glucocorticoids in these animals should be limited to beta-cells [21]. In accordance with this, no GR transgene expression was found in brain and liver and high expression of the transgene was demonstrated in beta-cells of transgenic mice, but not in control mice [21].

Therefore, the present results indicate that glucocorticoids enhance islet G6Pase activity by acting directly on beta-cells. Previously reported increased enzyme activity in islets of ob/ob mice after dexamethasone treatment $[2,7]$ was most probably also due to a direct hormonal action on beta-cells and not secondary to alteration of metabolism at other sites. The same mechanism probably explains the increase in the enzyme activity in normal mice treated with dexamethasone which we observed. Previously reported increased activity of G6Pase in ob/ob mice islets [2, 7] may have been due to increased corticosterone availability found in the animals [30].

An increased activity of islet G6Pase by $70 \%$ in transgenic mice increased islet glucose cycling threefold. Interestingly, islet glucose utilization and oxidation in transgenic mice were comparable with those in control animals, demonstrating that the enhanced glucose flux through G6Pase did not alter glucose utilization. Similarly, glucose utilization and oxidation were comparable in islets from ob/ob mice treated with dexamethasone or saline, although glucose cycling was increased from $36 \%$ to $56 \%$ following dexamethasone treatment [31]. These findings agree with in vitro studies, where dexamethasone had no ef- 
fect on glucose oxidation and $\mathrm{NAD}(\mathrm{P}) \mathrm{H}$ changes [32].

Previous studies described increased [33], unchanged [34], and decreased [35] insulin secretion upon administration of glucocorticoids to rats and mice. These results are difficult to interpret because of differing strains of animals and of doses and durations of administration of glucocorticoids. Glucocorticoids in vitro have also been reported to inhibit [34] or had no effect [36] on insulin release. In transgenic compared with control islets, glucose-induced insulin release was decreased and dexamethasone further decreased insulin release. In experiments with transgenic mice in vivo, the early insulin response to a glucose challenge was suppressed and glucose tolerance was decreased [21]. This provides direct evidence that glucocorticoids exert a diabetogenic effect via the suppression of insulin response, in addition to their other diabetogenic actions such as decreased glucose uptake and increased gluconeogenesis [15, 17]. This may be relevant to the increased incidence of diabetes mellitus in patients with Cushing's disease and patients treated with glucocorticoids [15, 37]. Inhibition of insulin release was not due to decreased insulin content in the islets, since content was similar in transgenic and control islets.

Our results confirm recent reports that dexamethasone inhibited insulin secretion by the islets in a concentration dependent manner and the inhibition was prevented by a blocker of nuclear glucocorticoid receptor $[32,38]$. In the insulinoma cell line, overexpressing 10-fold the hydrolase subunit of hepatic G6Pase, glucose cycling was increased 10-fold to $7.1 \%$ and insulin secretion was decreased by $30 \%$. However, unlike findings in our transgenic and ob/ ob mice, glucose utilization was decreased by $30 \%$ [20]. The reason for this apparent discrepancy is not clear.

Glucose stimulates insulin release by generating an increased ATP/ADP ratio which closes ATP sensitive $\mathrm{K}^{+}$-channels and depolarizes beta-cell membrane. This in turn results in increased $\mathrm{Ca}^{2+}$ influx and exocytosis of insulin [39]. Since an increased rate of glucose cycling in islets results in increased ATP consumption, a linkage is possible between the increase in cycling and G6Pase activity and the decrease in insulin release. The finding that in diabetic animal models increased cycling and phosphatase activity is associated with decreased glucose-induced insulin secretion [7,10-13] supports this possibility.

Acknowledgements. The study was supported by grants from the Swedish Medical Research Council (00034, and 13X2819), INSERM, Swedish Diabetes Association, Novo Nordisk, Karolinska Institute and National Institutes of Health (DK-14507). We thank Elvi Sandberg for skillful technical assistance.

\section{References}

1. Hellman B, Hellerström C (1962) Histochemical studies on glucose-6-phosphatase, adenosine triphosphate and amylo phosphorylase in the pancreatic islets of normal and obese-hyperglycemic mice. Diabetes 39: 474-482

2. Täljedal IB (1969) Presence, induction and possible role of glucose-6-phosphatase in mammalian pancreatic islets. Biochem J 114: 387-394

3. Ashcroft SJH, Randle PJ (1968) Glucose-6-phosphatase activity of mouse pancreatic islets. Nature 219: 857-858

4. Matschinsky FM, Ellerman JE (1968) Metabolism of glucose in the islets of Langerhans. J Biol Chem 243: 2730-2736

5. Waddell ID, Burchell A (1988) The microsomal glucose-6phosphatase enzyme of pancreatic islets. Biochem J 255: 471-476

6. Giroix MH, Sener A, Malaisse WJ (1987) Hexose metabolism in pancreatic islets. Absence of glucose-6-phosphatase in rat islet cells. Mol Cell Endocrinol 49: 219-225

7. Khan A, Hong-Lie C, Landau BR (1995) Glucose-6-phosphatase activity in islets from ob/ob and lean mice and the effect of dexamethasone. Endocrinology 136: 1934-1938

8. Sweet IR, Najafi H, Guizhu Li, Grodberg J, Matschinsky FM (1997) Measurement and modelling of glucose-6-phosphatase in pancreatic islets. Am J Physiol 272: E696-E711

9. Katz A, Rognstad (1976) Futile cycles in the metabolism of glucose. Curr Top Cell Regul 10: 237-289

10. Khan A, Chandramouli V, Östenson C-G et al. (1990) Glucose cycling is markedly enhanced in pancreatic islets of obese hyperglycemic mice. Endocrinology 126: 2413-2416

11. Kahn A, Chandramouli V, Östenson C-G, Löw H, Landau BR, Efendic S (1990) Glucose cycling in islets from healthy and diabetic rats. Diabetes 39: 456-459

12. Östenson C-G, Khan A, Abdel-Halim SM et al. (1993) Abnormal insulin secretion and glucose metabolism in pancreatic islets from the spontaneously diabetic GK rat. Diabetologia 36: 3-8

13. Cao H-L (1995) Increased glucose-6-phosphatase activity in islets from spontaneously diabetic GK rats. Diabetologia 38: A-143

14. Tokuyama Y, Sturis J, DePaoli AM et al. (1995) Evolution of beta-cell dysfunction in the male Zucker diabetic fatty rat. Diabetes 44: 1447-1475

15. McMahon M, Gerich J, Rizza R (1988) Effects of glucocorticoids on carbohydrate metabolism. Diab Metab Rev 4: 17-30

16. Lange AJ, Argaud D, El-Maghrabi RM, Pan W, Mitra SR, Pilkis SJ (1994) Isolation of a cDNA for the catalytic subunit of rat liver glucose-6-phosphatase: Regulation of gene expression in FAO hepatoma cells by insulin, dexamethasone and cAMP. Biochem Biophys Res Commun 201: 302-309

17. Wajngot A, Khan A, Giacca A, Vranic M, Efendic (1990) Dexamethasone increases glucose cycling, but not glucose production, in healthy subjects. Am J Physiol 259: E626-E632

18. Schmoll D, Allan BB, Burchell A (1996) Cloning and sequencing of the 5'region of the human glucose-6-phosphatase gene: transcriptional regulation by cAMP, insulin and glucocorticoids in H4IIE hepatoma cells. FEBS Lett. 383: 63-66

19. Lenzen S, Bailey CJ (1984) Thyroid hormones, gonadal and adrenocortical steroids and the function of the islets of Langerhans. Endocr Rev 5: 411-434

20. Trinh K, Minassian C, Lange AJ, O'Doherty RM, Newgard CB (1997) Adenovirus-mediated expression of the cataly- 
tic subunit of glucose-6-phosphatase in INS-1 cells. J Biol Chem 272: 24837-24842

21. Delauny F, Khan A, Cintra A et al. (1997) Pancreatic betacells are important targets for the diabetogenic effects of glucocorticoids. J Clin Invest 100: 2094-2098

22. Walker MD, Edlund T, Boulet AM, Rutter WJ (1983) Cellspecific expression controlled by the 5'-flanking region of insulin and chymotrypsin genes. Nature (Lond) 306: $557-561$

23. Arion WJ, Lange AJ, Walls HE, Ballas LM (1980) Evidence for the participation of independent translocases for phosphate and glucose-6-phosphate in the microsomal glucose-6-phosphatase system. J Biol Chem 255: 10396-10406

24. Anjaneyulu R, Anjaneyulu K, Carpinelli AR, Sener A, Malaisse WJ (1981) The stimulus-secretion coupling of glucose induced insulin release: enzymes of mannose metabolism in pancreatic islets. Arch Biochem Biophys 212: $54-62$

25. Wajngot A, Chandramouli V, Schumann WC, Kumaran K, Efendic S, Landau BR (1989) Testing of the assumptions made in estimating the extent of futile cycling. Am J Physiol 256: E668-E675

26. Herbert V, Lau KS, Gottlieb CW, Bleicher SJ (1965) Coated charcoal immunoassay of insulin. J Clin Endocrinol Metab 25: 1375-1384

27. Hinegardner RT (1971) An improved fluorometric assay for DNA. Anal Biochem 39: 197-201

28. Bradford MM (1976) A rapid and sensitive method for the quantitation of microgram quantities of protein utilizing the principle of protein-dye binding. Anal Biochem 72: 248-254

29. Vanderbitt JN, Miesfeld R, Maler BA, Yamamoto KR (1987) Intracellular receptor concentration limits glucocorticoid-dependent enhancer activity. Mol Endocrinol 1: $68-74$
30. Naeser P (1974) Function of the adrenal cortex in obesehyperglycemic mice. Diabetologia 10: 449-453

31. Khan A, Östenson C-G, Berggren P-O, Efendic S (1992) Glucocorticoid increases glucose cycling and inhibits insulin release in pancreatic islets of ob/ob mice. Am J Physiol 263: E663-E666

32. Lambillotte C, Gilon P, Henquin J-C (1997) Direct glucocorticoid inhibition of insulin secretion. J Clin Invest 99: 414-423

33. Malaisse WJ, Malaisse-Lagae F, Mc Craw EF, Wright PH (1967) Insulin secretion in vitro by pancreatic tissue from normal, adrenalectomized, and cortisol-treated rats. Proc Soc Exp Biol Med 124: 924-928

34. Chuthaputti A, Fletcher HP (1987) Effect of hydrocortisone on terbutaline stimulated insulin release from isolated pancreatic islets. Res Commun Chem Pathol Pharmacol 57: 329-341

35. Ogawa A, Johnson JH, Ohneda M et al. (1992) Roles of insulin resistance and beta-cell dysfunction in dexamethasone-induced diabetes. J Clin Invest 90: 497-504

36. Billaudel B, Sutter B (1979) Direct effect of corticosterone upon insulin secretion studied by three different techniques. Horm Metab Res 11: 555-560

37. Friedman TC, Mastorakos G, Newman TD et al. (1996) Carbohydrate and lipid metabolism in endogenous hypercortisolism: shared features with metabolic syndrome $\mathrm{X}$ and NIDDM. Endocr J 43: 645-655

38. Gremlich S, Roduit R, Thorens B (1997) Dexamethasone induces posttranslational degradation of GLUT 2 and inhibition of insulin secretion. J Biol Chem 272: 3216-3222

39. Ashcroft FM, Ashcroft SJH (1992) Mechanisms of insulin secretion. In Insulin. Oxford University Press, Oxford. pp $97-150$ 